\title{
The Reception of Figurative Art Beyond the Frontier: Scandinavian Encounters with Roman Numismatics
}

\author{
Nancy L. Wicker
}

The distribution of images of the Roman emperor, from portrait busts to miniature numismatic art, was key to the creation of the sprawling 'imagined community' of the Empire. ${ }^{1}$ Such images were ubiquitous across the empire, through the provinces and beyond, with coins reaching as far away as Scandinavia. In this paper, I present a case-study of a small number of fourthcentury Late Roman medallions that were brought to the North and inspired a new type of object, the Scandinavian gold bracteate of the Migration Period in the fifth and sixth centuries. My goal is to examine how the imagery of the medallions was received and imitated in the North, that is, the impact of the empire on Scandinavian visual representation. In this encounter, the miniature figural art of Roman medallions was incorporated into a culture that had an appreciation for animal ornamentation, had its own writing system in the form of runes, and used reciprocity and other forms of exchange before an incipient monetary economy began during the Viking Age late in the ninth or tenth century. ${ }^{2}$

With the influx of Roman coinage, Scandinavia played a role in the extended Empire simply by virtue of obtaining and using medallions. Although metal pendants with figural images had not been not part of the repertoire of northern goldsmiths prior to the Later Roman Iron Age of the third and fourth centuries $\mathrm{AD}$, medallions with suspension loops reached a receptive audience there. However, northerners adapted the essence of these fourth-century Imperial pieces into something that became emblematic of their own culture as they

1 The general idea of 'imagined communities' is introduced by Benedict Anderson, Imagined Communities: Reflections on the Origin and Spread of Nationalism, rev. ed. (London, 2006); and the concept is applied to the Roman Empire by Carlos Noreña, Imperial Ideals in the Roman West: Representation, Circulation, Power (Cambridge, U.K. 2011), 304.

2 Brita Malmer, 'South Scandinavian Coinage in the Ninth Century', in James GrahamCampbell, ed., Silver Economy in the Viking Age, Publications of the Institute of Archaeology, University College London (Walnut Creek 2007), 13. 
altered the physical characteristics, figural images, inscriptions, and functions of these objects. The numismatic type was modified but still traceable in the one-sided Nordic gold bracteates of the following century and a half. In this paper, I will first review how medallions may have been used and brought to the North and then I will summarize what we know about the use of Migration Period bracteates. ${ }^{3}$ After setting the stage with this background information, I will examine the artistic transformation of the portrait image from medallion to bracteate.

Medallions are multiples of the solidus that were made for ceremonial occasions and distributed by emperors to military leaders, who in turn gave them to soldiers to reward military valor and strengthen political bonds. ${ }^{4}$ The only extant documentary information about how these numismatic issues were used is a sixth-century account in which Gregory of Tours describes medallions that the emperor Tiberius had given to the Frankish king Chilperic. ${ }^{5}$ Although many medallions were framed and provided with loops for suspension, Gregory did not indicate whether Chilperic's pieces were plain or embellished.

Illustrations of men wearing pendants similar to medallions, as displayed on the late fourth-century silver ceremonial dish known as the Missorium of Theodosius and on the mid-sixth-century mosaic of Justinian I and his attendants at San Vitale in Ravenna, show how the display of comparable adornments was represented in monumental form and in the decorative arts. ${ }^{6}$ From Gregory's account and such visual parallels we reconstruct how medallions were dispensed to and worn by Germanic leaders, thus extending the reach of the 'imagined' larger community of the Roman Empire. The medallions are evidence not only of direct contact between the empire and Scandinavia, but

3 I examine this material in more detail in Nancy L. Wicker, 'Inspiring the Barbarians? The Transformation from Roman Medallions to Scandinavian Bracteates', in Peter S. Wells, (ed.), Rome beyond Its Frontiers: Imports, Attitudes and Practices. Journal of Roman Archaeology Supplementary Series 94 (Portsmouth, R.I. 2013), 105-120.

4 Nils Ludvig Rasmusson, 'Were Medals of Merit Used and Worn in Antiquity?' Acta Archaeologica 16 (1945), 211-222; and Valerie Maxfield, The Military Decorations of the Roman Army (Berkeley 1981).

5 Gregory of Tours, Historia Francorum 6.2 2. Lewis Thorpe (ed. and trans.), The History of the Franks (Harmondsworth 1974), 328.

6 John Beckwith, Early Christian and Byzantine Art, 2nd ed. (Harmondsworth 1979), 77, 114. 
also of the exchange of information between individuals and communities, thus of what may be discussed as the 'entanglement' of Rome and the North. ${ }^{7}$

In addition to genuine Roman medallions struck to the solidus standard under imperial control, barbarian medallion imitations were also produced, probably in Eastern Europe along the Danube or in the Black Sea area, as ascertained by significant finds of such artifacts in these areas. ${ }^{8}$ The imitations mimic the appearance of their medallion models and were made by the same methods, yet they routinely were looped and thus intended to serve as ornamentation rather than coinage. The very production of imitations demonstrates that there was interest in these objects and a desire for more of them than was afforded by the supply of authentic multiples that reached Barbaricum. Both medallions and their imitations were distributed broadly, even to the far north (Fig. 12.1), ${ }^{9}$ leading us to conjecture whether the individuals who used them were familiar with Roman customs and the usage of such objects.

Seven fourth-century Roman medallions as well as thirteen imitations have been found in Denmark, Norway, and Sweden. ${ }^{10}$ The imitations were struck by the same numismatic methods as genuine coins, with figures (and often inscriptions) in low relief on both obverse and reverse; the emperor's head

For discussion of the concept of 'entanglement', see Ian Hodder, Entangled: An Archaeology of the Relationships between Humans and Things (Malden, Mass., 2012); and Michael Dietler, Archaeologies of Colonialism: Consumption, Entanglement, and Violence in Ancient Mediterranean France (Berkeley 2010).

Alexander Bursche, 'Roman Gold Medallions as Power Symbols of the Germanic Élite', in Bente Magnus (ed.), Roman Gold and the Development of the Early Germanic Kingdoms," Konferenser $5^{1}$ (Stockholm, 2001), 92; and Helle Horsnæs, Crossing Boundaries: An Analysis of Roman Coins in Danish Contexts. Vol. 1: Finds from Sealand, Funen and Jutland. Publications of the National Museum. Studies in Archaeology and History 18 (Copenhagen 2010), 187 .

9 Bracteates (and medallion imitations found in Scandinavia) are cited with catalogue numbers "IK" (= Ikonographische Katalog) for the 7-volume catalogue organized by Karl Hauck, et al., Die Goldbrakteaten der Völkerwanderungszeit (Munich 1985-1989).

All photographs in this chapter are licensed under Creative Commons, as follows:

"Bilder i Sök i samlingarna är, om inte annat anges, licensierade för icke-kommersiell användning som kopiering, distribution och visning med en http://www.creativecom mons.se/?page_id=92 Creative Commons-licens. På bildens sida länkas till gällande licens och där kan du se detaljer kring licensen och hur du får använda bilden. Du har rätt att kostnadsfritt använda bilden för icke-kommersiellt bruk enligt licensen om du anger fotograf/upphovsman, källa ("Historiska museet" eller "sнm")."

The exact numbers depend upon whether a strict or loose definition of 'medallion' is used. See Wicker, 'Inspiring the Barbarians?' 105. 


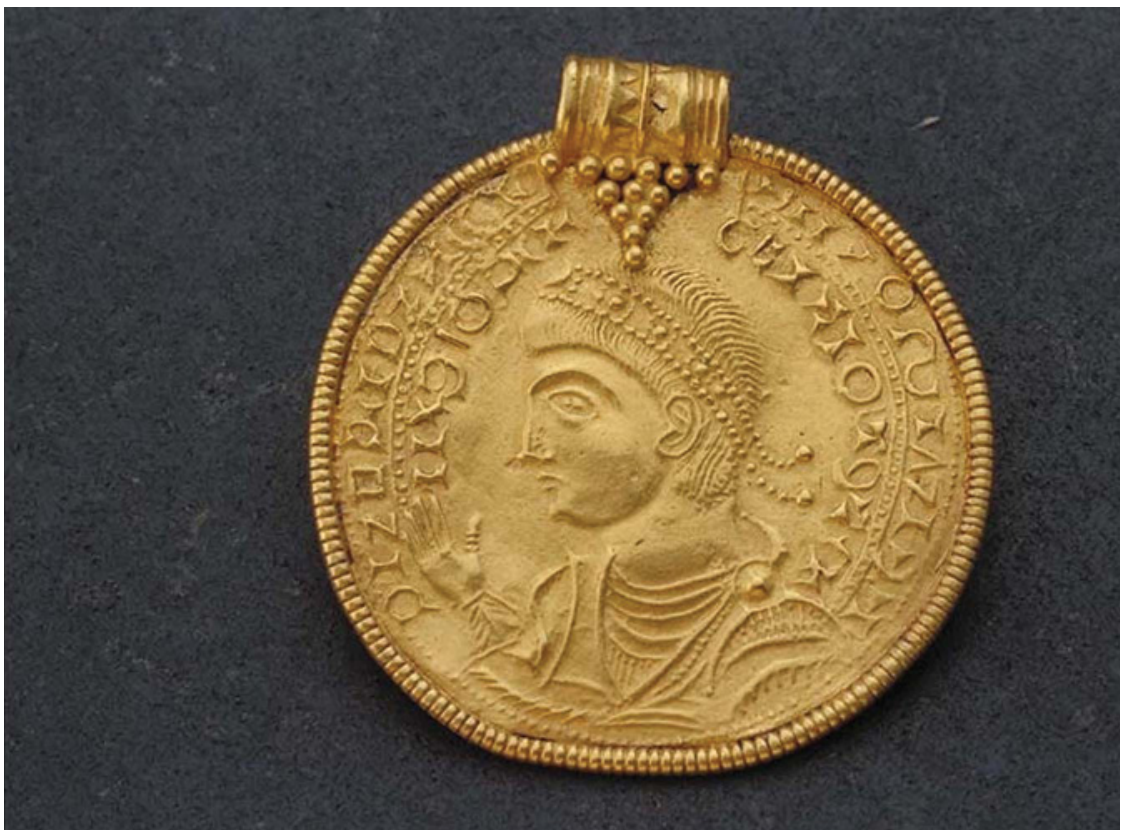

FIGURE 12.1 Medallion imitation (IK 107), from LillaJored, Bohuslän, Sweden; Statens Historiska Museet, Stockholm, inv. no. 421; diam. $3.9 \mathrm{~cm}$.

(PHOTOGRAPH NO. 14710 BY ULF BRUXE, SHM 1993-06-18)

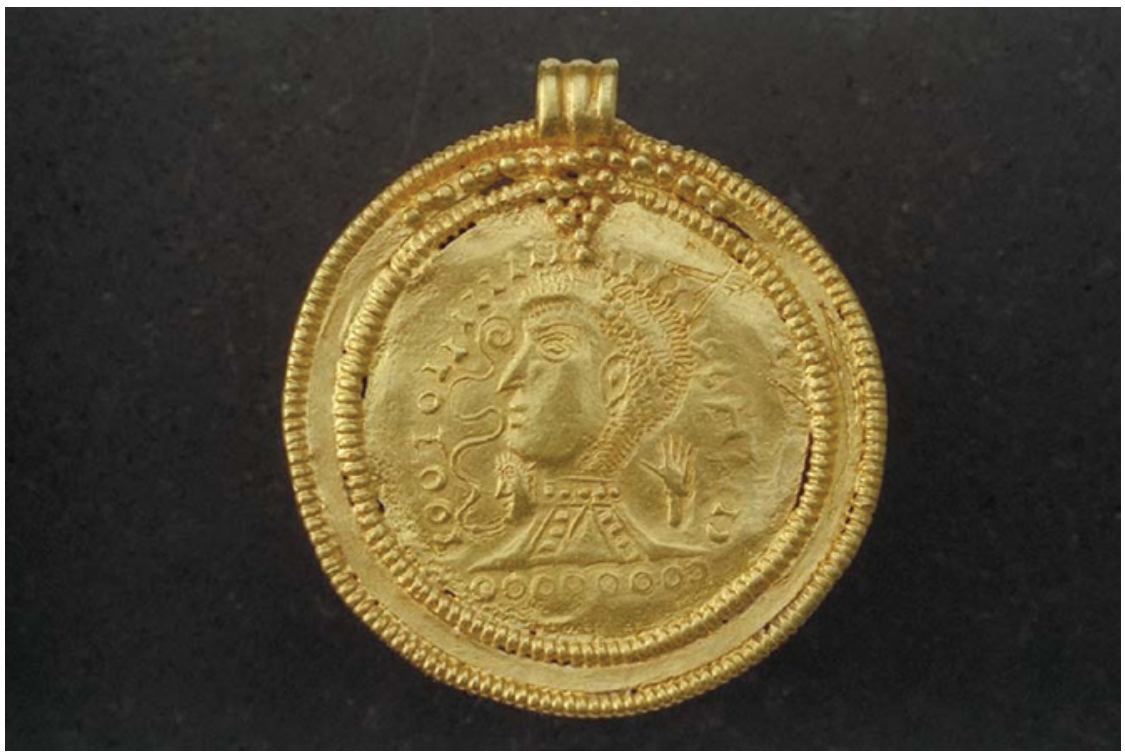

FIGURE 12.2 Medallion imitation (IK 14), from Aneby, Småland, Sweden; Statens Historiska Museet, Stockholm, inv. no. 20510; diameter $3.76 \mathrm{~cm}$.

(PHOTOGRAPH NO. 13558 BY ULF BRUXE, SHM 1993-08-02) 
is depicted and the Roman letters are sometimes clear, yet both pictures and inscriptions are frequently corrupted (Fig. 12.2).

How the solidus multiples and their imitations reached the North is unknown; nonetheless, it is presumed that they were brought by men who had obtained them as diplomatic gifts or as rewards for meritorious military service in the auxiliaries. ${ }^{11}$ The promise of citizenship upon retirement is often cited as an enticement for barbarian enlistment in the military, although documentation of actual Scandinavian participation in the imperial forces is lacking. ${ }^{12}$ We know little about how medallions and imitations were used in the North, and the fact that all but one of these examples were discovered in the nineteenth century as stray finds or from sites not excavated to modern standards hinders the assignment of gender to what may have been cremation and inhumation burials. ${ }^{13}$ All of these pieces discovered in Scandinavia have (or preserve traces of) suspension loops with signs of wear, so we deduce that they were worn. Ultimately, the nature of the adaptation from the Roman model that is evident on the medallion imitations prefigures a more extended process of reinterpretation that continues with the Nordic artifacts known as bracteates.

\section{Bracteates}

As looped pendants with figurative images and sometimes with inscriptions, Scandinavian Migration Period gold bracteates superficially resemble Roman medallions (Fig. 12.3).

Although similar to medallion imitations in that they were made for display rather than coinage, bracteates differ significantly from medallions and their imitations in their one-sided technique and usage of runic characters instead of Roman capitals. ${ }^{14}$ The change in production method from numismatic two-sided striking to bracteate one-sided stamping is a matter of both

\footnotetext{
11 Alexander Bursche, 'Die römischer Goldmedaille in der Spätantike', in Wilfried Seipel, ed., Barbarenschmuck und Römergold: Der Schatz von Szilágysomlyó (Vienna 1999); and Bursche, 'Roman Gold Medallions'.

12 Maureen Carroll, Romans, Celts and Germans: The German Provinces of Rome (Stroud, 2001), p. 105; and Gad Rausing, 'Barbarian Mercenaries or Roman Citizens?' Fornvännen 82, nos. 2-3 (1987), 126.

13 Wicker, 'Inspiring the Barbarians?' 113-116; and Kent Andersson, Romartida guldsmide i Norden, III: Övriga smycken, teknisk analys och verstadsgrupper. Occasional Papers in Archaeology 13 (Uppsala 1995), 44-45.

14 Wicker, 'Inspiring the Barbarians?' 105-120.
} 


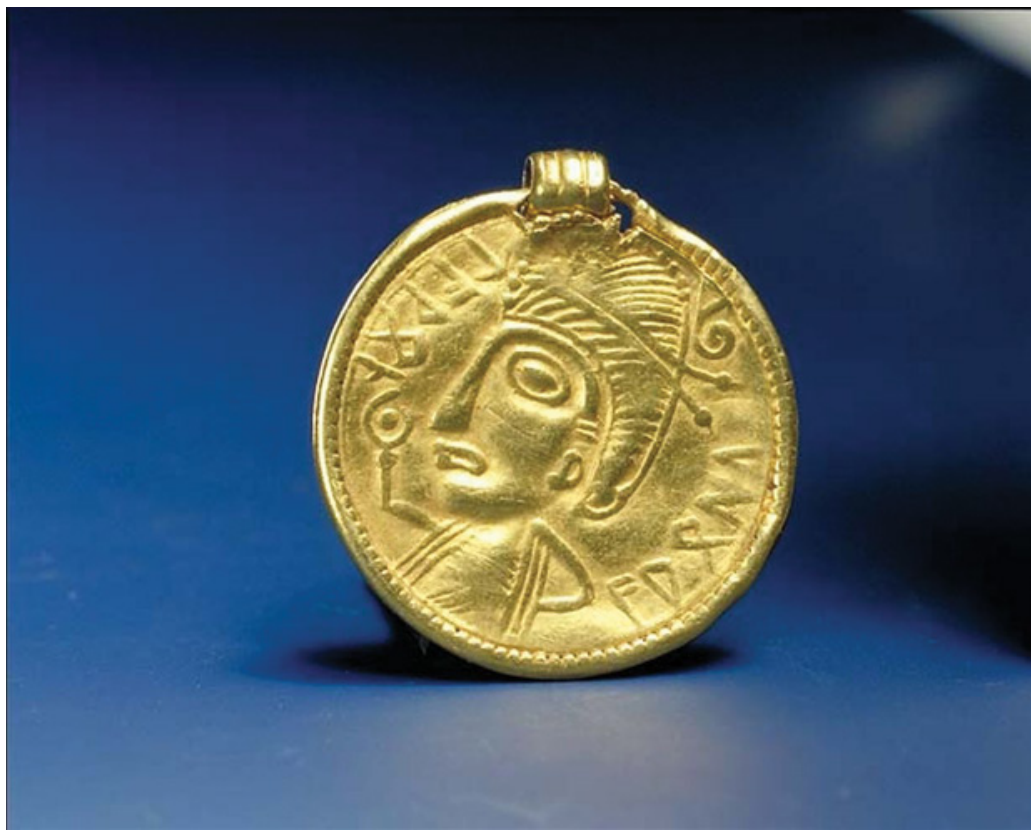

FIGURE 12.3 Type A bracteate with runic inscription (IK 189), from Trollhättan, Västergötland, Sweden; inscription: tawol apodu (indecipherable); Statens Historiska Museet, inv. no. 1164; diam. $2.33 \mathrm{~cm}$.

(PHOTOGRAPH NO. 17633 BY GUNNEL JANSSON, SHM 1995-07-31)

technology and economics - stamping is easier to execute and can be accomplished with very thin metal, thus requiring less gold than medallions struck from two sides simultaneously. While interest in continuing the foreign concept (although not the technique) was demonstrated, substituting Germanic runes for Roman letters demonstrates that the southern model was adapted to a local, northern audience.

Inscriptions on some bracteates include Proto-Scandinavian words lapu (invitation), laukaR (leek), and alu (ale) that Anders Andrén proposes reflect the general significance of Latin dominus, pius, and felix on coins and medallions. ${ }^{15}$ Though his rather convoluted argument has not been accepted by philologists, ${ }^{16}$ Andrén's suggestion that the words were of equivalent impor-

15 Anders Andrén, 'Guld och makt—en tolkning av de skandinaviska guldbrakteaternas funktion', in Charlotte Fabech and Jytte Ringtved (eds.), Samfundorganisation og regional variation: Norden i romersk jernalder og folkevandringstid. Jysk Arkæologisk Selskabs Skrifter 27 (Højbjerg 1991), 248-252.

16 Henrik Williams, in Nancy L. Wicker and Henrik Williams, 'Bracteates and Runes', Futhark: International Journal of Runic Studies 3 (2012, publ. 2013), 194. 
tance rather than the same literal meaning may be on the right track to explain how bracteates rendered ideas pertinent to Germanic society. In addition, the degree of similarity between figural images on medallions and on bracteates reveals that there was still a continuing connection to and entanglement with the Roman background. Was this link due to a long-term memory of foreign ties held by certain members of Nordic society? If medallions found in the North were brought there by soldiers who had served as mercenaries, how long after the return of these men to their home did knowledge of representations of the emperor survive? Did the tradition of medallions as gifts in reward for loyalty persist with bracteates in Scandinavia? An examination of who used these objects and how they exploited them may shed light on whether the Roman tradition was indeed carried on.

\section{Use of Medallions, Imitations, and Bracteates in Scandinavia}

Our limited testimony for the usage of medallions from Gregory of Tours and various visual sources leads us to believe that men on the Continent were awarded these objects and wore them suspended around their necks as marks of military distinction. Without such documentary and visual evidence in Scandinavia, we look for contexts that help us understand how they were treated. As noted earlier, we lack sufficient reliable information about find circumstances of medallions and have only little more evidence for the imitations. A triple solidus of Valentinian (r. 367-375) from Vestre Hauge in Norway may be from a female burial, as ascertained by the presence of beads typically worn by women, whereas three imitation medallions are believed to come from male and two from female burials, also on the basis of characteristic gendered grave goods. ${ }^{17}$ Notwithstanding the small numbers of examples, the contextual archaeological evidence challenges the male interpretation of the admittedly inadequate visual and documentary material by demonstrating a female connection to these objects. A possible shift in gendering the function of pendants from male to female may signal a conscious or unconscious rejection of the Roman tradition of how to display medallions-a shift in usage that was carried further with bracteates.

With over one thousand bracteates extant, ${ }^{18}$ we have sufficient information about find contexts to tempt us to assess the gendered use of some them, even

17 Andersson, Romartida guldsmide i Norden, 43-45; and Åsa Dahlin Hauken, The Westland Cauldrons in Norway. AmS-Skrifter 19 (Stavanger 2005), 78.

18 In December 2010, 1003 bracteates were known, according to Morten Axboe, 'Die Chronologie der Inschriften-Brakteaten', in Wilhelm Heizmann and Morten Axboe (eds.), Die 
though stray finds during agricultural work and undocumented finds account for a large number of them, approximately thirty percent. ${ }^{19}$ Roughly fifteen percent were discovered in burials and fifty-five percent in hoards-caches of materials buried in the ground perhaps for safekeeping or as offerings. ${ }^{20}$ The geographic distribution of find types is not uniform. In southern Scandinavia, the core area of bracteate discovery, hoards are ubiquitous, whereas burials dominate in the more peripheral areas of the distribution, including western Norway, the island of Gotland, England, and Continental Europe except for the northernmost areas of Germany and Poland — where, as in neighboring southern Scandinavia, they are found in hoards. ${ }^{21}$ Almost all of the graves in which bracteates were deposited are judged to be female burials according to grave goods and skeletal analysis, allowing that there are considerable difficulties with such assignments. ${ }^{22}$ The bracteates are looped and lay on the chest area as pendants, usually in association with other jewelry. The few examples from male burials have no loops and thus were not suspended as pendants; instead their find circumstances reveal that they were used in other ways - two were Charon's obols discovered in the mouth cavity and one was lying along the side of the body as if in a cloth or leather bag. ${ }^{23}$ Interestingly, the composition of many bracteate hoards reflects the sets of women's jewelry normally found in burials, ${ }^{24}$ thus raising the question of whether the hoards as well as the typical burials were gendered female and reiterating the need to examine how bracteates were associated with women.

While medallions and medallion imitations may have been presented by men to other men, following the Roman custom, we have little information about their subsequent use. In regard to military decorations, Valerie

Goldbrakteaten der Völkerwanderungszeit-Auswertung und Neufunde. Ergänzungsbände zum Reallexikon der Germanischen Altertumskunde 40 (Berlin 2011), 296.

19 I cite percentages of various find contexts from my personal database of bracteate finds.

20 Richard Bradley, The Passage of Arms: An Archaeological Analysis of Prehistoric Hoards and Votive Deposits (Cambridge 1990).

21 For a distribution map marking the find contexts, see Andrén, 'Guld och makt', 248.

22 See for instance Bettina Arnold, 'Gender and Archaeological Mortuary Analysis', in Sarah Milledge Nelson, ed., Handbook of Gender in Archaeology (Lanham, Md. 2006), 137-170.

23 See Morten Axboe, 'Der Brakteat aus Roirhage und seine Verwandeten. Zum Problem der Charonspfenninge in Skandinavien', in Jan Peder Lamm and Morten Axboe, 'Neues zu Brakteaten und Anhängern in Schweden', Frühmittelalterliche Studien 23 (1989), 465-473; and D.R.J. Perkins and Sonia Chadwick Hawkes, 'The Thanet Gas Pipeline Phases I and II (Monkton Parish), 1982', Archaeologia Cantiana 101 (1984), 105.

24 John Hines, 'Ritual Hoarding in Migration-Period Scandinavia: A Review of Recent Interpretations', Proceedings of the Prehistoric Society 55 (1989), 193-205. 
Maxfield suggests that 'When not being worn...the dona would presumably be deposited somewhere safe..... Alternatively, they might be put on display'. ${ }^{25}$ Scandinavians apparently resisted following the foreign model of how such objects were given and exhibited, perhaps breaking the mold already with medallions - which are found occasionally with women-but certainly with bracteates, which we find displayed on women's bodies. How did women initially obtain bracteates? Birgit Arrhenius suggests that these objects were given by men to women, perhaps as bride-price. ${ }^{26}$ Once in the hands of women, they may have been inherited by their daughters as Sonia Hawkes proposes, and thus they passed through the female line. ${ }^{27}$ Yet, just as medallions indicated high status for soldiers who received them as gifts, bracteates would remain a marker of the elite-now expressed as a new behavior centered on women rather than men. Henceforth, women carried forward the tradition of wearing pendants with figural imagery based on the Roman emperor's portrait, and the figural image on bracteates was subsequently redistributed over much of Europe in the later fifth and sixth centuries as jewelry worn by females. In these new environments, the revised symbol of empire encountered other traditions (Anglo-Saxon, Byzantine, Merovingian, etc.) that continued the thread from Roman art in a different manner.

\section{$4 \quad$ Figural Imagery}

Although schematic stick-figure humans were common in rock carvings of the Late Bronze Age (ca. 1100-500 BC) in Scandinavia, figural art was rare and alien in this region throughout the Iron Age-from the Pre-Roman Iron Age (ca. 500 BC-AD 50) continuing through the Viking Age (ca. AD 800-1050). A few three-dimensional wooden sculptures are known, including a priapic figure from Broddenbjerg bog in central Jutland, C-14 dated to $535-520$ в ${ }^{28}$ and a seated effigy from Rude Eskilstrup on Zealand, dated to the 5 th century AD

\footnotetext{
25 Maxfield, Military Decorations, 143.

26 Birgit Arrhenius, 'Smycken som diplomati', in Katarina Ågren (ed.), Föremål som vittnesbörde: En festskrift till Gertud Grenander Nyberg på 8o-årsdagen den 26 juli 1992 (Stockholm 1992), 18-25.

27 Sonia Chadwick Hawkes and Mark Pollard, 'The Gold Bracteates from Sixthcentury Anglo-Saxon Graves in Kent, in the Light of a New Find from Finglesham, Frühmittelalterliche Studien 15 (1981), 339.

28 Klaus Ebbesen, 'Broddenbjerg-manden: en gudestatue og andre gudestatuer fra bronzealderen', Fra Viborg-egnen, 76 (2011), 37-48.
} 
based on the neck-ring depicted on the man. ${ }^{29}$ However, two-dimensional graphic figures were particularly avoided in the North. I would like to consider this scarcity in the context of Ernst Gombrich's examination of the seemingly obvious observation that the expression of 'mimesis' (imitation of the natural world) is more direct in the actual three-dimensionality of sculpture than in the creation of the illusion in painting and drawing. ${ }^{30}$ Thus in many cultures, including Iron Age Scandinavia, figures on a flat or nearly flat surface (allowing for low relief) are abstracted even though sculptural works in the same tradition may be relatively representational.

When the human figure is visible in Iron Age Scandinavia, often only the head or face is included. For instance, so-called 'Celtic' masks executed in sculptural relief are displayed on the Gundestrup cauldron, which was found in Denmark although presumably imported from elsewhere, perhaps southeastern Europe. ${ }^{31}$ 'Celtic' full-face masks show what Gombrich calls the 'distinctive features' of a human face - two eyes, a nose, and a mouth - the attributes that are focused on in artwork by children and the unschooled as well as the 'primitive. ${ }^{32}$ On the other hand, the profile bust in bas relief, introduced into Scandinavia on Roman coinage from the Republican Period onwards, ${ }^{33}$ relies on what Gombrich explains as 'seeing' rather than 'knowing.. ${ }^{34}$ The frontal image, used occasionally on bracteates (Fig. 12.4), depends upon the artist's knowledge of what constitutes a face rather than actual perception of what is seen, whereas the side view is dependent upon or connected to direct observation of the subject.

29 Birgit Arrhenius, 'Järnåldern', in Stenåldern, Bronsåldern, Järnåldern, Signums svenska konsthistoria 1 (Lund, 1994), 189-190; and Hans Jørgen Frederiksen and Inger-Lise Kolstrup, Ny Dansk Kunsthistorie, vol. 1. Troens kunst (Copenhagen 1993), 23.

30 Ernst H. Gombrich, The Preference for the Primitive: Episodes in the History of Western Taste and Art (New York 2002), 271-273.

31 The origin of the Gundestrup cauldron is disputed. Helmut Birkhan notes its connections to Thracian metalwork and proposes its manufacture around 100 BC. Kelten: Bilder ihrer Kultur/Celts: Images of Their Culture (Vienna 1999), 17, 25.

32 Gombrich, The Preference for the Primitive, 274.

33 Helle W. Horsnæs, Crossing Boundaries; and Aleksander Bursche, 'Roman Coins in Scandinavia: Some Remarks from the Continental Perspective', in John Pind et al., ed., Drik-og du vil leve skønt: Festskrift til Ulla Lund Hansen på 7o-årsdagen 18. August 2002. Publications from the National Museum, Studies in Archaeology and History 7 (Copenhagen 2002), 69-78.

34 Gombrich, Art and Illusion: A Study in the Psychology of Pictorial Representation, rev. ed. (Princeton 1961), 300; Gombrich carries his discussion further in The Preference for the Primitive, 273. 


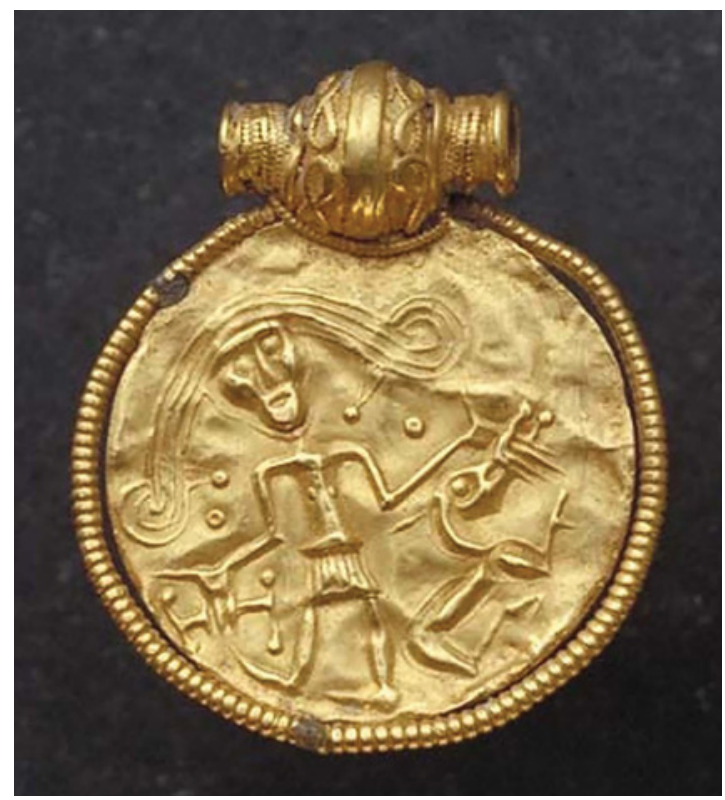

FIGURE 12.4 Full-face human head on Type B bracteate (IK 19o), from Trollhättan, Västergötland, Sweden; Statens Historiska Museet, Stockholm, inv. no. 1164; diam. $2.8 \mathrm{~cm}$ (PHOTOGRAPH NO. 14602 BY ULF BRUXE SHM 1993-07-08).

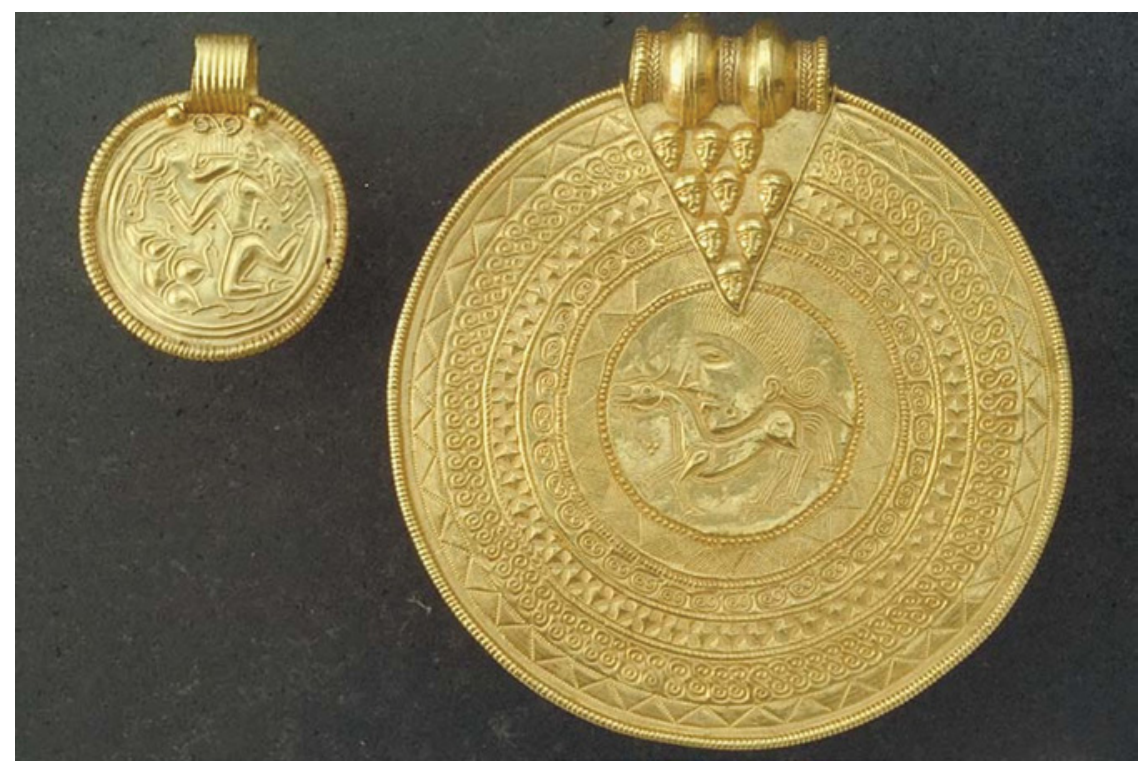

FIGURE 12.5 Profile heads on Type B bracteate (IK 143), diam. $2.86 \mathrm{~cm}$, and Type C bracteate (IK 144,1), diam. 7.32 cm, both from Ravlunda, Scania, Sweden; Statens Historiska Museet, Stockholm, inv. no. 71; (PHOTOGRAPH NO. 14058 BY ULF BRUXE SHM 1993-07-30). 
Fourth-century Roman medallions and medallion imitations exhibit the profile emperor's portrait, and over half of the approximately one thousand fifthand sixth-century bracteates - most of those known as Types A (Fig. 12.3), B (Fig. 12.5), and C (Fig. 12.5) —also display a profile human head. ${ }^{35}$

Crucial for the dating of bracteates are numerous fifth- and sixth-century solidi that are found in bracteate hoards and provide a terminus post quem. ${ }^{36}$ The later solidi show the emperor in three-quarter view rather than the profile of the earlier medallions. Consequently, it seems curious that the bracteates in these hoard finds did not follow the model of the contemporary solidi; instead they continue to harken back to the fourth-century prototypes. As an explanation for this unexpected situation, Helle Horsnæs proposes that fourth-century Roman coins 'must have been visible above ground into at least the mid-5th century', a view shared by Morten Axboe. ${ }^{37}$ If goldsmiths who produced bracteates looked directly at these early models, they must have copied and re-copied the profile view, which became further disassociated from direct observation. Peter Stewart reminds us that coin portraits referred to a prototype $^{38}$ so bracteates copy a model that was already removed from the portrait. In Gombrich's terms, the Scandinavian bracteate profile image was made through 'knowledge' of what a medallion (or bracteate) should look like rather than 'perception' of what an emperor looked like. The image was executed using the minimum elements necessary for recognition of the head as the Roman idea of a portrait was reinterpreted in a society that did not have 'the figurative habit'.39

35 Oscar Montelius first classified the Migration Period bracteates into Types A through D, groupings that still form the framework for the iconographic study of these objects; see Montelius, Från jernåldern (Stockholm 1869). The large profile head of the emperor is traceable on Types A and C, whereas a smaller profile head is seen on Type B examples that show schematic full-figures with arms and legs. Type D consists of purely animal ornamentation with no humans.

36 Morten Axboe conveniently lists these finds in an appendix to Die Goldbrakteaten der Völkerwanderungszeit-Herstellungsprobleme und Chronologie. Ergänzungsbände zum Reallexikon der Germanischen Altertumskunde 38. (Berlin 2004), 321-326.

37 Horsnæs, Crossing Boundaries, 157; and Axboe Die Goldbrakteaten der Völkerwanderungszeit, 265 .

38 Peter Stewart, 'Gell's Idols and Roman Cult', in Robin Osborne and Jeremy Tanner, eds., Art's Agency and Art History (Oxford 2007), 170.

39 I adapt the phrase 'the sculptural habit' used by Peter Stewart in, 'Geographies of Provincialism in Roman Sculpture', RIHA Journal 5 (27 July 2010), <http://www.riha-journal .org/articles/2010/stewart-geographies-of-provincialism > (accessed 11 August 2014). 
Emulating a medallion was not an easy task; in a discussion of the origin of bracteates, Haakon Shetelig remarks straightforwardly that 'coin relief is a difficult art, which is not easily improvised'. ${ }^{40}$ As the technique of the relatively thick, two-sided struck coin was abandoned in Scandinavia in favor of the thin, one-sided stamped ornament of bracteates, the style of representation was also modified. Instead of the subtle, modeled low relief of numismatic art, we now see schematic, embossed linear designs. Both technique and style change, yet the head of a man is still recognizable even though it appears in a flattened composition as if drawn with raised outlines (sometimes doubled outlines) rather than modeled in volumes. In addition, the layout constrained within a small, round field seems to have posed a dilemma in a culture that was unfamiliar with either figural or coin design. ${ }^{41}$ We may speculate about how much of the transformation from medallion to bracteate was related to the modification of techniques and how much to a desire to show Nordic subject matter rather than an alien leader, but it is too simplistic to attribute the adaptation to one or the other of these factors. Most likely, it was both. Eventually the figural image on Scandinavian bracteates no longer represented a memory of the idea of the Roman emperor; instead it may have denoted their own secular leader, a religious leader, or a Nordic deity-but we should not assume that these categories are mutually exclusive or that all bracteate images refer to the same subject. ${ }^{42}$

40 Haakon Shetelig, Classical Impulses in Scandinavian Art from the Migration Period to the Viking Age. Instituttet for sammenlignende kulturforskning, series A: Forelesninger 19 (Oslo 1949), 48.

41 I have posed this question elsewhere, see Wicker, 'The Scandinavian Animal Styles in Response to Mediterranean and Christian Narrative Art', in Martin Carver, ed., The Cross Goes North: Processes of Conversion in Northern Europe, AD 300-1300 (Woodbridge 2003), $535^{-536 .}$

The identification of the human figure is an enormous issue in bracteate studies that cannot be taken up here. Some of the major viewpoints are taken by Gunilla ÅkerströmHaugen, who traces Roman iconography on bracteates in Genesis och metamorphosis: En studie i de nordiska guldbrakteaternas ikonografi. Gothenburg Studies in Art and Architecture 31 (Gothenburg 2010); Elmar Seebold, who proposes that the figure is a secular Germanic leader in 'Römische Münzbilder und germanische Symbolwelt: Versuch einer Deutung der Bildelemente von C-Brakteaten', in Heinrich Bech, Detlev Ellmers, and Kurt Schier, eds., Germanische Religionsgeschichte: Quellen und Quellenprobleme. Ergänzungsbände zum Reallexikon der Germanischen Altertumskunde (Berlin 1992), 270-335); and Karl Hauck, who has dominated the discussion of bracteate iconography for a generation with his interpretation of the imagery on bracteates as early indication of Nordic mythology that is better known through Old Norse literature of the medieval period, in numerous works, but most recently in the summation in 'Machttaten Odins: Die 
What can we learn from medallions and bracteates about the impact of the Roman Empire in Scandinavia? The influx of medallions into the North did not stimulate the development of coinage in the Iron Age non-monetary economy; however, exposure to the figural imagery of medallions was productive and stimulated a vigorous and creative local response. Additionally, medallions were agents that served as wearable emblems to express elite status. These socially-significant artifacts were first adopted and then adapted for use in the North-renegotiated and modified, as discussed by Fraser Hunter. ${ }^{43}$ In a case-study of Roman objects found beyond the frontier in Scotland, Hunter examines material that was 'incorporated into local ways of doing things' and that then 'affected those habits'. In a similar way, medallions were consumed and incorporated into elite practice in Scandinavia and then stimulated an indigenous response-bracteates - that adapted the portraits as stylized linear designs and replaced the Roman letters with Germanic runic characters. The usage of the objects, too, was altered-from men's bestowal of military awards to women's display of family wealth and status. Yet the result was still connected at least tangentially to the larger community of the empire. In particular, the continuing use of the profile human image 'entangled' bracteates with medallions and with Roman culture. The tie to the foreign concept was unbroken, and the impact of the empire is evident as the semantic language of figural art — the very idea of representing humans in pictorial form-reached Scandinavia, far beyond the frontier.

Chiffrenwelt der Brakteaten und die Methoden ihrer Auswertung', in Wilhelm Heizmann and Morten Axboe, eds., Die Goldbrakteaten der Völkerwanderungszeit-Auswertung und Neufunde. Ergänzungsbände zum Reallexikon der Germanischen Altertumskunde 40 (Berlin 2011), 1-6o.

43 Fraser Hunter, 'The Lives of Roman Objects beyond the Frontier', in Peter S. Wells, ed., Rome beyond its Frontiers: Imports, Attitudes and Practices. Journal of Roman Archaeology Supplementary Series 94 (Portsmouth, R.I. 2013). 